\title{
More Than Forty Amish Affiliations? Charting the Fault Lines
}

\author{
Christopher Petrovich ${ }^{1}$
}

Independent Researcher

Niška Banja, Serbia

\begin{abstract}
The Amish are notoriously difficult to chart in terms of affiliations. However, defining affiliations is important to researchers: as a suitable measurement of conservatism, as a useful context for making sense of a particular district or settlement, for tracing socio-religious change over time, and for depicting both the unity and diversity that characterize contemporary Amish socio-ecclesiastical life. Until recently, scholars followed John Hostetler's definition of an affiliation as a group of church districts that fellowship together and share a common Ordnung. But in The Amish, Donald Kraybill, Karen Johnson-Weiner, and Steven Nolt offer an entirely new definition of an affiliation as a cluster of two or more districts with at least twenty years of shared history. They conclude that there are at least 40 Amish affiliations. I argue against this haphazard fragmentation, identifying six major affiliations and a handful of outliers. I then apply my traditional-modified model to several scenarios to demonstrate the model's utility.
\end{abstract}

\section{Keywords}

Amish affiliations; Amish denominations; New New Order Amish; New Order Christian Fellowship; New Order Amish; Old Order Amish; Andy Weaver Amish; Kenton Amish; Swartzentruber Amish; Kraybill, Johnson-Weiner, and Nolt The Amish; Holmes County, Ohio; Adams County, Indiana 


\section{Introduction}

The Amish, taken as a whole, are notoriously difficult to chart in terms of affiliations. While affiliations are clear on a settlement level, inter-settlement relationships are much murkier (Johnson-Weiner 2014). This situation stems from the localized nature of their churches. Nevertheless, defining Amish affiliations is important to researchers: as a suitable measurement of conservatism, as a useful context for making sense of a particular district or settlement, for tracing socio-religious change over time, and for depicting both the unity and diversity that characterize contemporary Amish socio-ecclesiastical life. In this article, I clarify recent confusion about Amish affiliations, responding to Donald Kraybill, Karen Johnson-Weiner, and Steven Nolt's (2013) claim that there are more than forty affiliations. I argue against their haphazard fragmentation, identifying six major affiliations and a handful of outliers.

In conventional usage, an affiliation would be defined as a group of congregations that officially attach or connect to a larger body. However, the Amish lack formal bureaucratic structures beyond the church district. Amish affiliations exist when church districts willingly associate with one other. Because individual church districts do not pledge support to a higher organization that has a codified set of beliefs and practices and whose decisions are binding on its constituency, it is not possible to conceptualize affiliation in exclusively organizational terms.

Local decision-making not only makes it difficult to conceptualize Amish affiliations in terms of organizational structure, it also leads to a lack of clearly definable boundaries. Because individual church districts decide which church districts to associate with, church districts within the same affiliation do not always fellowship with identical church districts. And there are two degrees of association-full and partial fellowship. The lack of clearly definable boundaries and varying degrees of association within a single affiliation make it difficult to operationalize affiliations for social scientific analysis.

In Amish Society, John Hostetler defines an affiliation as a group of church districts that fellowship together and share a common Ordnung (Hostetler 1993). This definition was largely adopted by later scholars, with only minor modifications made along the way. It was generally assumed that there are four affiliations-Swartzentruber, Andy Weaver, Old Order, and New Order_ - or perhaps a few more (Kraybill 1994; Hurst and McConnell 2010; Meyers and Nolt 2005). But in The Amish, Kraybill, Johnson-Weiner, and Nolt (2013) offer an entirely new definition of an affiliation as a cluster of two or more districts with at least twenty years of shared history. Parsing Amish society on the basis of shared local history, they conclude that there are more than forty affiliations. This proposal not only redefines (re-conceptualizes) affiliation, it also operationalizes the definition with dramatically different results.

This article traces affiliation usage in broad outline from Hostetler's first revised edition of Amish Society (1968) to An Amish Paradox (Hurst and McConnell 2010); analyzes the conceptual basis for, and practical outworking of, Kraybill, Johnson-Weiner, and Nolt's new 
definition; identifies five characteristics of an affiliation and six distinct affiliations; and demonstrates my traditional-modified model's strength through three scenarios.

\section{From Amish Society (1968) to An Amish Paradox (2010)}

Scholars have largely taken up Hostetler's definition of affiliation in Amish Society (1968) and refined it. An affiliation is a socio-ecclesiastical term denoting a group of church districts that fellowship together and share common disciplinary procedures and technological restrictions.

In the first revised edition of Amish Society, Hostetler identifies three social groupings above the family level—settlement, church district, and affiliation. He defines an affiliation as "a group of church districts that have a common discipline and that commune together" (Hostetler 1968, 93). For Hostetler, what most frequently divides the Amish into distinct affiliations are liberal-progressive interpretations of Ordnung. The Amish tend to classify church districts according to degrees of worldliness, putting them on a sliding scale from "low" (or conservative) to "high" (or progressive/liberal). Although they lack uniform definitions of conservative and progressive/liberal, Hostetler identifies three lenses though which the Amish determine the worldliness of a church district: strictness of discipline (the subject is often strict shunning), degree of separation from the world, and level of tolerance for modern technology (whether the congregation permits balers in the field, portable electric generators, battery tools, propane lights, etc.).

In Amish Society, Hostetler (1968) charted the Mifflin County settlement according to degrees of worldliness. Of the thirteen groups that Hostetler placed in concentric circles from low to high, only the first five groups were Amish. Also, the Byler church has exchanged ministers with the Renno group since 1948. And when clusters of church districts part ways with other districts in the same settlement, these local clusters nearly always establish working relationships with like-minded districts in other communities, reducing the total number of affiliations in Amish society. This is the case with the Mifflin County Peachey Amish (Renno church) as it is in full fellowship with the Lancaster County Amish. These cross-settlement ties are not evident in Hostetler's presentation and largely neglected in the model proposed by Kraybill, Johnson-Weiner, and Nolt, as will be shown below.

In The Riddle of Amish Culture, Kraybill (2001) followed Hostetler's three basic units of social organization - settlements, districts, and affiliations. He defined an affiliation as a group of congregations that are in spiritual fellowship. Affiliated congregations "follow similar religious practices and cooperate with each other” (pp. 13-14). Cooperation indicates a strong social bond while similarity of religious practice suggests an ecclesiastical or spiritual dimension.

Thomas Meyers and Steven Nolt (2005) follow traditional usage in An Amish Patchwork, noting that the Amish themselves employ fellowship language to indicate which congregations they associate with. The authors also observe that an affiliation is different than a settlement even 
though some settlements are aligned with a single affiliation. An affiliation is primarily social and spiritual rather than spatial, a mistake that is made in the new definition proposed by Kraybill, Johnson-Weiner, and Nolt.

In An Amish Paradox: Diversity and Change in the World's Largest Amish Community, authors Charles Hurst and David McConnell (2010) state that "A cluster of church districts that share similar Ordnung are said to be ‘in fellowship’ with each other and are called an affiliation” (p. 16). Hurst and McConnell distinguish full from partial fellowship, identifying those who are in partial fellowship as exchanging ministers for preaching duties in church services and funerals and districts in full fellowship allowing ministers to assist in the administration of communion services. Although Holmes County is one of the most diverse Amish settlements in North America, Hurst and McConnell explain that four affiliations account for roughly $97 \%$ of all church districts. Rather than perplexing readers with a long list of affiliations by parsing the major affiliations and listing out the remaining 3\%, the authors help readers make sense of the diversity of the Holmes County Amish—a strength of the traditional model.

In their work on plain Anabaptist groups, Cory Anderson and Joseph Donnermeyer (2013) suggest that there are two types of affiliations - a local affiliation and a broad affiliation. A local affiliation is the spatial cluster of local churches that fellowships with each other and shares a similar vision. In a settlement where there are multiple districts of the same affiliation, each church district earns a reputation for progressive, moderate, or conservative tendencies. Nevertheless, each district's primary identification remains with the local affiliation. A broad affiliation exists when a local affiliation is part of a larger network, often spread across multiple states or countries. Rather than trying to integrate specific spatial boundaries into "affiliation" (as happens with the new definition proposed by Kraybill, Johnson-Weiner, and Nolt), Anderson and Donnermeyer affix adjectives_-local and broad—-to add a simple spatial element to the term.

In recent decades, scholars have largely followed Hostetler's definition of affiliation in Amish Society (1968), making only minor tweaks along the way. None of these modifications altered the fundamental criteria for identifying an affiliation — on the basis of lines of fellowship and shared disciplinary procedures, technology usage, and degrees of separation from the world - that lay at the root of Hostetler's definition, at least until Kraybill, Johnson-Weiner, and Nolt’s new (2013) proposal.

\section{A Proliferation of Affiliations: Problems with the New Kraybill, Johnson- Weiner, and Nolt (2013) Definition}

In The Amish, Donald Kraybill, Karen Johnson-Weiner, and Steven Nolt (2013) propose a new definition of an affiliation:

An affiliation, as we define it, is a cluster of two or more districts with at least twenty years of shared history. Affiliated congregations share similar Ordnungs, which specify distinctive lifestyles and visible symbols that set them apart from other affiliations. These interwoven features create a unique 
identity that is expressed in use of technology and consumer products, style of architecture, levels of income, degree of social isolation, and types of occupation as well as in hairstyles, dress patterns and carriage color and style. Members of an affiliation have a collective awareness of in-group membership and are known as a distinctive group within Amish society and, sometimes, by nonAmish people. (p. 138)

This definition accounts for cultural differences between settlements, recognizing that traditions (carriage colors and styles, dress patterns, etc.) have developed differently because of shared local history. Table 8.1 provides visual representation of this diversity. Indeed, diversity is a significant interpretive paradigm of The Amish, based on the dramatic shift that the authors claim - from three or four Amish affiliations at the beginning of the twentieth century (p. 138) to more than forty in 2012. But the authors fail to define and apply the term in a consistent manner.

How many affiliations existed at the turn of the twentieth century? According to Table 8.1, the answer is, at least fifteen (not three or four as they state on the previous page) because the chart identifies the following affiliations as having been established before 1900: Lancaster, Elkhart-LaGrange, Holmes, Swiss (Adams), Swiss (Allen), Nappanee, Arthur, New Wilmington, Daviess, Renno, Kalona, Milverton, Somerset, Byler, and Kokomo.

How many affiliations existed in 2012? According to Table 8.1, more than 40. So there are more than 40 groups “defined by shared views and practices”? This seems unlikely. The key to understanding the discrepancies are the different definitions being employed. Affiliations are identified "by shared views and practices" in the first full paragraph of page 138 while a paragraph later an affiliation exists when a cluster of church districts have twenty years of shared history, and it seems this qualification is adjoined to the preceding definition when formulating Table 8.1.

Kraybill, Johnson-Weiner, and Nolt's definition of affiliation can be critiqued in four areas: their arbitrary selection of Ordnung and cultural differences in defining affiliations, their conflation of settlement and affiliation, their irregular use of "shared history," and the uselessness of their groupings as a scale of ordinal data.

\section{Arbitrary Selection of Differences to Define Affiliations}

Central to the authors' definition of affiliation are differences in the Ordnung-directed “distinctive lifestyles” and "visible symbols.” As examples, they refer to technology, consumer products, architecture, income, social isolation, occupations, clothing and hair styles, and buggy types. Most problematic is that the parsing-game is endless; what is an important lifestyle / symbolic difference worth distinguishing an affiliation and what is not? Ultimately, Table 8.1 ends up carving out groupings by cultural differences that the Amish consider irrelevant to affiliation while at times ignoring Ordnung differences that have created splinters. Furthermore, the authors rarely clarify which symbols and practices are the basis of defining a difference. 
A mere glimpse into intra-settlement divisions demonstrates this point. For example, while the authors identify two separate Geauga County, $\mathrm{OH}$, Amish groups, they fail to recognize even a second affiliation in Adams County, IN, even though the Adams County settlement has splintered into at least five non-communing fellowships (Nolt and Meyers 2007; Scott 2011). They are just "Swiss Amish," perhaps their propensity to yodel being the key "distinctive lifestyle" practice that binds them into one affiliation. And similarly, the Lancaster County, PArelated Amish settlements have extensive Ordnung differences but no acknowledgement is made of new Lancaster "affiliations” based on such differences, even when the Amish themselves recognize such Ordnung differences (e.g. a separate network of St. Mary's County, MD daughter settlements, represented in their own directory).

As another case, Kraybill, Johnson-Weiner, and Nolt admit that "the five dozen Gmays that permit tractors for tilling and harvesting in the field are sometimes lumped together as "Tractor Amish" even though they are not an affiliation but simply districts in various settlements that happen to share this atypical custom" (p. 140). Here is a case where they reveal the symbolic basis in defining a group. However, much is made out of one single Ordnung practice that, in reality, has no basis on which to be included into a list of affiliations, even by the authors' own admission. "Tractor Amish” is a residual grouping that salvages some districts from the miscellaneous “other” category but only evidences the awkwardness of the authors' schema. And then other apparently higher-identity, tractor-permitting settlements (e.g. Kokomo, IN, and Kalona, IA) are salvaged from the "tractor Amish" category, as if there's an implied hierarchy about how genuine an affiliation really is! The only apparent basis for these higher order settlements being distinguished from "Tractor Amish" is that these two communities have been around for a long time - having 150+ years of history - while other communities, including Choteau, OK, and Garnett, KS - are just not good enough to be their own affiliations, having but a mere $100+$ years of history.

The problem with hair-splitting over subjective differences is that Amish districts in full fellowship are sliced into separate affiliations. Consequently, affiliations are not grouped together according to similarities in the Ordnung practices that matter most to the Amish. For example, the thirty-eight districts that make up the Joe L. group in Adams County (IN) have Ordnungen that are similar to the Kenton $(\mathrm{OH})$ churches and are in full fellowship with the Kenton circle but Table 8.1 identifies them as distinct affiliations, presumably because they do not meet other, inconsequential criterion, including migration history and Swiss vs. non-Swiss cultural differences.

Another case-in-point are buggy style differences. The Swartzentruber Amish do not permit a storm front or tall dashboard on their buggies; this restriction matters to them and would likely keep them from uniting with Amish districts in LaGrange County (IN) even if these groups were able to agree on all other points of faith and practice. This is a case where an Ordnung practice correctly distinguishes affiliations. However, that the buggies in LaGrange County are made according to a slightly different pattern than the ones in Holmes County (OH), Arthur (IL), 
and Jamesport (MO) is more a matter of historical circumstance; it has not caused a breach in fellowship for these churches. Nevertheless, Table 8.1 claims that these settlements are separate affiliations, even though the congregations in each of these settlements are in full fellowship with one another.

\section{Conflating Settlements with Affiliations}

The arbitrary delineation of cultural differences hints at the next critique: Kraybill, Johnson-Weiner, and Nolt frequently define an affiliation as what is actually a settlement (and that settlement's most immediate daughter settlements). Settlements are not affiliations; rather, they are spatial concentrations of districts that across several generations have developed some localized characteristics. Calling settlements "affiliations” is hyper-sensitive to differences that have no usefulness to researchers, let alone to the Amish themselves.

For example, Kraybill, Johnson-Weiner, and Nolt use the settlement as the primary social unit when they divide Indiana's Elkhart-LaGrange, Nappanee, and Kokomo settlements into three distinct affiliations, even though these groups have nearly identical beliefs, lifestyle practices, culture, and historical origin (from Holmes County in the 1840s). Elkhart-LaGrange, Nappanee, and Kokomo are settlements, not affiliations (Meyers and Nolt 2005). And then, inconsistent at another level, they lump all New Orders together despite equally similar settlement-based distinctiveness, consolidating settlements such as Guthrie (KY), Oakland (MD), and Holmes County (OH).

\section{“Shared History” Irregularly Applied as a Definer of Affiliation}

Similarly, Kraybill, Johnson-Weiner, and Nolt give undue weight to shared history in defining affiliations and ignore it in other places where it suits them. For example, the Abe Miller and Kenton churches have nearly identical beliefs and lifestyles, and the two groups are in full fellowship, but Table 8.1 identifies them as distinct groups, presumably because the Abe Millers originated from the Swartzentrubers while the Kenton circle was started by a group of families that moved out of Elkhart-LaGrange in the 1950s. Meanwhile, the Jamesport-Bloomfield settlements are combined despite their very different historical circumstances of establishment. The Ordnung in Arthur is almost identical to the Ordnung in Elkhart-LaGrange but these are classed as two distinct affiliations, presumably due to differing shared histories, while a host of churches including Buchanan County (IA), Medford (WI), Bowling Green (MO), Clark (MO), and yet others in New York and Ontario are lumped together possibly due to shared disciplinary practices but ultimately in spite of their hodge-podge histories. Based on the preceding observations, sometimes shared history alone trumps lines of fellowship, shared disciplinary standards, and common Ordnung stances, while at other times it is inconsistently omitted.

More problematic, the 20 years of shared history criterion is not followed through consistently. Why 20? The authors do not say. Hypothetically, then, every new settlement could achieve affiliation status after 20 years. The Young Center for Anabaptist and Pietist Studies 
(2016) reports that there are just over 500 geographical settlements. According to their own definition, more than 500 affiliations could exist by 2036. Rather than following their reasoning to its logical end, the authors are more likely to stop somewhere in-between but without clear criteria for enumerating Amish affiliations, as happened when they claimed that there is a Somerset County (PA) and Dover (DE) affiliation but not an Oakland (MD), Centreville (MI), or St. Mary’s County (MD) affiliation-founded 1850, 1910, and 1940 respectively. The new definition threatens to reduce affiliations to complex lists of settlements, enumerating every settlement that has existed for at least 20 years and subdividing those settlements where ecclesiastical rifts have occurred-maybe (Geauga County) or maybe not (Adams County).

\section{Affiliation Scheme Presented as a Nominal Scale Rather Than a More Useful Ordinal Scale}

In Table 8.1, affiliations are organized with no relation to one another. The only criterion for their order is size based on district numbers, which holds little to no usefulness, especially in light of the illogical way affiliations were constructed. More valuable for empirical studies would be a scale that defined relationships among affiliations (that is, affiliations as ordinal—not nominal—data). Both scholars and the Amish identify "low" (conservative/traditional) groups such as the Swartzentrubers and "high" (liberal/progressive) groups such as the New New Order; this suggests an ordinal relationship among affiliations. Unfortunately, Table 8.1 makes no such distinctions, probably because of the haphazard identification of what is an affiliation and the impossibility of doing any ranking under such conditions.

\section{Conclusion}

The Amish are a very diverse religious body, but diversity is hardly unique to the Amish. People in groups the world over manage to forge meaningful levels of unity in spite of the potential for infinite, ultimately individualizing, diversity. In positing more than 40 affiliations, Kraybill, Johnson-Weiner, and Nolt enter into an untenable and subjective selection of which criteria matter most through innumerous comparisons, forcing together puzzle pieces that do not belong together while separating ones that do. One is left with the sense that a list the late Stephen Scott (1948-2011) likely used to catalog cultural differences in dress, architecture, and technology (as found in his three books on these topics and an unpublished 2011 paper)—but not necessarily all-encompassing bonds of fellowship_-was inappropriately promoted to the level of "full affiliation." The definition is thereby useless. Scott, who never published a list of Amish "affiliations" in his lifetime despite many opportunities to do so, may well have recognized the problems it would cause. He instead cataloged practices by a selection of places, but never total. Ultimately, the crime of forcing a definition of "affiliation" on these $40+$ groups is that it neglects the ties that bind church districts in different settlements together, leaving it a fragmented, factious world, which does not parallel reality. 
Given these critiques, I find their definition irreparable and suggest it should be discarded in favor of another. In the next section, I present in a narrowly defined set of tangible variables how the concept "affiliation” can be more usefully operationalized.

\section{Five Characteristics of an Affiliation: The “Traditional-Revised” Model}

The preliminary criterion for defining an affiliation is the fellowship bond Amish themselves establish. However, if these were entirely consistent, affiliation would be defined easily. Because they are not entirely consistent, additional defining characteristics are necessary. An Amish affiliation is definable through five attributes: shared identity, disciplinary procedures, technology usage, theological beliefs, and community practices. These five attributes produce six major affiliations: Swartzentruber, Kenton, Andy Weaver, Old Order-mainstream, New Ordertraditional, and New New Order. None of the five attributes can be taken alone as the sole measure of Amish affiliations, for each in itself produces some contradictions. Yet, in the list, earlier characteristics are weighed more heavily against the latter, where discrepancies exist among the five. And ultimately, exceptions will exist, and I address these later. The vast majority of the Amish, though, can be classified into one of six affiliations based on the guidance of these five variables; this I will call the "traditional-revised" model, since it builds on the commonly accepted affiliations prior to Kraybill, Johnson-Weiner, and Nolt’s (2013) proposed revisions.

\section{Shared Identity Arising from Historic Breaches in Fellowship}

A new “circle of churches” is typically identified with one or more early leaders and the beliefs or practices that caused a breach in fellowship in an historical moment or collection of moments. These moments are characterized as when church leaders are put out of a larger fellowship or withdraw voluntarily when they believe differences between congregation sets are too great to continue fellowshipping. Though splinters seem routine across Amish history, the ones that can be considered affiliations are those whose developments are felt across multiple Amish churches - even settlements - rather than those arising from incidental circumstances at a local level. New affiliations are real possibilities when matters must be addressed at a Dienerversamlung level.

From inception and across time, an affiliation takes on a life of its own. Its identity changes as its congregations and church leaders blaze a new path in new circumstanceschanges in technology, theological influences from Mennonite and Evangelical groups, and their broader Sitz im Leben. This unique identity always "is" but is also in the process of "becoming." Distinct identities frequently lead to sharpened borders among Amish affiliations and contribute to the diversification of the contemporary Amish world.

\section{Disciplinary Procedures}

Congregations within an affiliation share similar, though not necessarily identical, disciplinary procedures. The religious practice that presents the clearest line of Amish affiliations 
is the use of excommunication and shunning, for it speaks of what Amish churches view as acceptable and unacceptable deviations from their own churches. Positions on excommunication and shunning have been an ongoing source of contention for nearly their entire history. It centers on this practical question: if an Amish church represents an assembly of true believers, and the assembly is responsible for the religious well-being of members once members commit to them, then at what point have members who have left this assembly moved beyond the realm of what the Gmay is able to recognize as a devout brotherhood of similar values? The answer to the question says as much about how the church views itself as it does its relationship with similar churches. The most immediate question of consequence regarding defectors is, "Who should be excommunicated and shunned?" not how they implement the shunning. There are four different ways that excommunication and shunning are implemented: three versions of strict shunning (Streng Meidung) and one of non-strict shunning (Meidung).

Congregations excommunicating and shunning a member for joining any non-Amish church-usually identified by automobile ownership—practice "strict shunning." Swartzentruber, Kenton, and Andy Weaver congregations implement this form of discipline. But the vast majority of Old Orders don't, and the New Order-traditional and New New Orders don't either. These Old and New Orders will remove the membership of a person who leaves the Amish, but they will not shun ex-members as long as they join another plain, non-resistant (e.g. Mennonite or Amish-Mennonite) group. Some congregations excommunicate and shun until the former member gains membership in another plain, non-resistant congregation, but this practice is slowly fading.

Among congregations that practice strict shunning, three different policies exist. First, the Swartzentruber Amish shun anyone who leaves their group, no matter what type of church they associate with in the future. Second, the Kenton Amish shun anyone who goes "too high," and this includes joining progressive Old Order church districts. And third, the Andy Weaver Amish excommunicate and shun anyone who leaves the Amish, that is, joins a car church.

Although Amish congregations are routinely placed in one of two camps-those that practice strict shunning and those that don't — there are actually four discrete positions on the subject of excommunication and shunning. These four approaches contribute to the contemporary diversity of Amish life but also bind congregations together.

\section{Technology Allowances and Prohibitions}

Technology usage has been a defining characteristic since the late nineteenth-century, when Bishop Yost H. Yoder and numerous families (now known as "Nebraska Amish") broke fellowship with the other Amish in Mifflin County (PA) in order to return to the dress pattern and lifestyle a half-century previous. In 1909, the Swiss Amish in Allen County (IN) divided into Schmucker and Graber factions over the use of steam engines and grain binders. Within a decade, Bishop Sam Yoder and his followers separated from other Amish church districts in 
Holmes County $(\mathrm{OH})$, at least partly to stem technological change. It was around this time that automobile ownership was rejected by the main body of Amish churches. Henceforth, nonownership and the non-operation of automobiles has been the most visible technological line that defines the Amish from the non-Amish, including from churches with deep roots in the Amish tradition such as the Amish-Mennonites.

Today, there is a wide range of technological positions among the Amish, from the nomotor Swiss Amish to districts that permit smartphones. Technology is an ongoing source of contention among the Amish, and yet, despite this tension, several salient technological markers distinguish the core of each Amish affiliation, even as districts on the liberal and conservative periphery of each affiliation blur the affiliation's boundaries (demanding the weighing-in of other characteristics).

The New Order-traditional and New New Order Amish are the most technologically progressive, permitting tractors in the fields and electricity from the public utility lines. The main exception is the New Order-traditional in Holmes County $(\mathrm{OH})$ which do not permit either of these innovations. In other words, they are just as technologically conservative as some church districts among the mainstream Old Orders in large settlements. The New New Orders, by contrast, tend to pursue technological innovations as much as possible, just as long as they are able to retain non-ownership and non-operation of motor vehicles, thus allowing them to stay within the Amish fold.

The Old Order Amish-mainstream encompass the widest range of technological positions, from the rather conservative "Missouri churches” (Windsor, Dixon, Humansville, etc.) that do not allow electrical generators or fax machines to districts in Shipshewana that permit smartphones. What defines the center of the Old Order-mainstream is the rejection of personal automobile ownership as a visible symbol of separation from the world; rejection of all audiovisual media technology that would invite unwanted influences into the home (this may be changing among the most progressive districts, who wink at family DVD players); and the practice of self-denial by remaining “out of step” with society by selectively adopting new technologies-more slowly than the New New Orders but not to the extent of the most traditional Amish groups. Although there is some overlap between New Order-traditional and Old Order Amish-mainstream practices, technology usage provides a fairly reliable measure for determining which affiliation a church district belongs to, with other affiliation-defining characteristics helping to clarify.

The most progressive districts in the Andy Weaver affiliation have technology usage similar to the "Missouri churches" but for the most part the Andy Weaver affiliation is easily distinguishable from the Old Order-mainstream by their "minimalist attitude toward technology..." (Petrovich 2014) but without believing that less technology necessarily brings a community closer to God, as is the case among more traditionalist affiliations. The most conservative Andy Weaver congregations, such as the three districts on the north side of Gladwin 
(MI), are nearly as restrictive as the Kenton affiliation-no indoor toilets, no refrigerators, no bulk tanks, no air or hydraulic in shops, and no SMV emblems on buggies. However, the Kenton Amish are more uniform, consistently less tolerant of technology than the most restrictive Andy Weaver districts. Notably, the Kenton Amish will not fellowship with any church district that permits pressurized lanterns or traveling to work with an automobile.

The Swartzentruber Amish are the most restrictive. They do not allow dust collection systems in shops, do not affix SMV emblems to their buggies, do not allow stained trim in their homes, and, in most cases, only permit one kerosene lantern for lighting on their carriages. The Swartzentruber Amish believe that the more they are able to deny themselves modern technologies, the closer they are to God. They believe that self-denial of this type conforms to Jesus' teachings in the Sermon on the Mount and the Christian ideal of humility. Their approach to technology is simple - the least is best. For the Swartzentruber Amish, simplicity is an ethical principle of chief importance.

\section{Theological Beliefs}

Amish affiliations can also be distinguished on the basis of theological emphases, notably humility theology vs. evangelical theology. The most significant theological divide in the Amish world is between those who openly emphasize evangelical theology and those who don't.

From the beginning, the New Order-traditional in Holmes County have unashamedly embraced an evangelical theology. Other New Order church districts were disfellowshipped by Old Orders because they permitted tractors in the field and electricity from the public utility line. But over the years, these New Order groups have also embraced an evangelical theology-an emphasis on the doctrine of the new birth and belief in the assurance (experiential knowledge) of salvation. ${ }^{2}$ The New New Order Amish share this evangelical theology of salvation but emphasize that the new birth is the experience of the individual, downplaying the role of ordained ministers compared to other Amish groups.

Old Order-mainstream ministers regularly grapple with evangelical emphases, uncertain how to explain the doctrine of salvation or relate this doctrine to their lives without separating faith and works or feeling that they are embracing a worldly (non-Amish) theology.

Although the Amish emphasize practice more than doctrine, the Swartzentruber, Kenton, and Andy Weaver Amish routinely excommunicate and shun a member who publicly professes belief in the assurance of salvation, a token of evangelical beliefs. The Swartzentruber Amish have the strongest version of "humility" theology. This emphasis is less pronounced as we move across the spectrum to the Kenton and Andy Weaver Amish. Among the mainstream Amish, there is a strong emphasis on humility but it is more a humility of submitting to the overarching Old Order church structure and less about living a "lowly" lifestyle. There are also degrees of emphasis on the experiential aspect of religion, the Swartzentruber Amish placing the least and the New New Orders the most emphasis on this aspect. 


\section{Table 1: Characteristics of Amish Affiliations}

\section{Name of}

Affiliation

\section{Characteristics}

Church discipline: Excommunicates anyone who leaves the Swartzentrubers or moves to a non-communing Swartzentruber faction

Technology: Among the most restrictive: SMV emblems not permitted on carriages; no motors in the fields; dust collection systems not permitted in shops; may not hire drivers except in emergency situations, and others

Swartzentruber Theological beliefs: Encourage ministers to quote rather than interpret the Bible; strong humility theology

Community practices: Pipe smoking accepted; distinctive dress style such as men's hair completely covering the ears; bean soup served at church meal; retention of other traditionalist practices

Shared identity: Sided with Bishop Sam Yoder in Holmes County Amish division in the early 1900s

Church discipline: Excommunicates those joining a district considered too technologically permissive or that teaches assurance of salvation

Technology: Forbids pressurized lanterns and travel to work in automobiles Theological beliefs: Emphasizes Sermon on the Mount; moderately strong Kenton humility theology

Community practices: Smoking and bed courtship forbidden; highly traditional dress styles

Shared identity: Withdrew from larger Old Order settlements beginning in the 1950s; later separated from Andy Weaver affiliation; other church districts came over from the Swartzentruber Amish in recent years

Church discipline: Excommunicates and shuns any member who joins a nonAmish or New New Order congregation

Technology: Considerable variation but rarely tolerates generators, milking machines, air compressors, mobile phones, or word processors

Andy Weaver Theological beliefs: Does not teach assurance of salvation; more likely than above affiliations to explain the new birth doctrine and quote Epistles of Paul Community practices: Varies considerably among communities but moderately to highly traditional in dress and architectural styles Shared identity: Sided with Bishop Andy Weaver in strict shunning division in Holmes County in 1955

Old OrderChurch discipline: Minority of congregations practice strict shunning, most mainstream do not shun members that leave the Amish as long as they join an Anabaptist church that practices non-conformity to the world 
Old Ordermainstream (continued)
Technology: Few church districts forbid milking machines or generators; steel wheels on buggies increasingly uncommon; some permit word processors and mobile phones

Theological beliefs: Humility theology not connected with living conservative lifestyle but encourages members to lay down individual preferences to keep the mainstream Old Orders together as one group; tend to steer away from the assurance of salvation but considerable variation regarding evangelical emphases

Community practices: More accommodating to society than traditionalist groups: tolerates higher lifestyles and amenities such as flower gardens, paved driveways, hunting trips, educational vacations, etc.

Shared identity: Broad Amish identity; tend to see themselves within the narratives of the largest and oldest communities

Church Discipline: Disciplines members primarily for moral failings, rarely for joining a different Anabaptist church community

Technology: Usage of "Non-electric" districts similar to majority of mainstream Old Order districts; "Traditional Electric" districts permit electricity from public utility lines and tractors in field (and often on the road) but not mobile phones or computers

New Ordertraditional Theological beliefs: Emphasizes doctrine of new birth; teaches assurance of salvation; promotes humanitarian outreach to local community

Community practices: Community work bees; organized youth activities with parental oversight; hands-off courtship; women wear cape on dress every day and dress length generally longer than among Old Order women; tobacco and alcohol forbidden

Shared identity: Traditional electric — moral emphasis that separates them from mainstream Old Orders since late 1950s; Non-electric - moral/spiritual emphasis that separates them from mainstream Old Orders since late 1960s

Church Discipline: Rarely discipline for joining a different church Technology: Most permissive of all Amish groups; permit tractors in the field and on the road, electricity from public utility line, computers, and smartphones with internet access

New New

Order
Theological beliefs: Evangelical and missionary emphasis; teach assurance of salvation; stronger sense of unity with other church groups

Community practices: Similar to New Order practices except that leadership role is less pronounced and activities tend to include church groups with whom they hold values in common

Shared identity: Separated from Non-electric New Orders in late 1970s; later joined by "New Order" side of Tobe division from the 1960s 


\section{Community Practices}

A narrow list of community practices - namely, the holy kiss, courtship standards, youth meetings, Sunday School, tobacco usage, and dress patterns for women-are longstanding hotbutton issues that have marked Amish affiliations.

In the 1960s, certain Old Order-mainstream families in the Holmes County (OH) settlement practiced the holy kiss not only by older men and ministers but by church members of all ages, men with men and women with women. Differences on this issue, as well as the propriety of youth meetings and Sunday School-that is, holding a shorter church service on the in-between Sunday-led to the emergence of a new affiliation in the Holmes County settlement, the New Order Amish. All New Order-traditional and New New Order hold Sunday school. Old Order, with a few exceptions including Kalona and Somerset, do not. New Order-traditional women are further distinguishable from other Amish women by wearing a cape on the dress at home during the week, not merely during church services and when visiting in public. And in spite of converging views on technology, a strong commitment to hands-off courtship keeps the New Order-traditional from merging with the Old Order-mainstream.

On the lower end of the spectrum, the Kenton Amish refuse to fellowship with the Swartzentruber Amish because of their tolerance for smoking and bed courtship. Some Andy Weavers also refuse to fellowship with church districts that allow members to use tobacco.

\section{Summary}

The traditional model of an affiliation as "a group of church districts that fellowship together and share a similar Ordnung" is better understood as a group of church districts that fellowship together and share similar historic identities, disciplinary procedures, restrictions on technology, theologies, and community practices, with differences weighted according to circumstances. A summary of meaningful affiliation differences is presented in Table 1.

The bond of fellowship is the primary criterion for identifying church districts as an affiliation. Beyond that, it is shared identity rooted in an historical schism, then disciplinary procedures, with the other three characteristics weighted according to the situation. Taken together, these five constitute axes on which affiliations situate themselves, yet are not necessarily equal. For example, with New Order Amish affiliations, theology and community practices distinguish them from others, though both were wedded to mid-century movements out of the Old Order. In the case of the Swartzentruber Amish, technology and disciplinary procedures are the defining features of their affiliation. This even introduces an irony, where the bond of fellowship can be severed, yet, for all practical purposes, the groups remain an affiliation proper. Their most severe strict position on excommunication and shunning (anyone leaving our group) requires an anomaly, that members leaving for other Swartzentruber factions be shunned as well, even as these various Swartzentruber fellowships share similarities in most every other way, not the least of which is their common origin in the 1910 Sam Yoder division. 


\section{Applying the Definition to Holmes County (OH), Adams County (IN), and the 40+ "Affiliations"}

The utility of my traditional-modified model of affiliation will now be demonstrated through three cases: the well-researched Holmes County, OH, settlement; the less researched Adams County, IN, settlement; and, finally, a collapsing of the Kraybill, Johnson-Weiner, and Nolt's 40+ affiliations. The break-down of the six affiliations in the five largest settlementsincluding Holmes and Adams - is presented in Figure 1. Until recently, there was also Andy Weaver representation in Northern Indiana and New Order in Lancaster.

\section{Figure 1: Affiliations by District Numbers in the Five Largest Settlements}

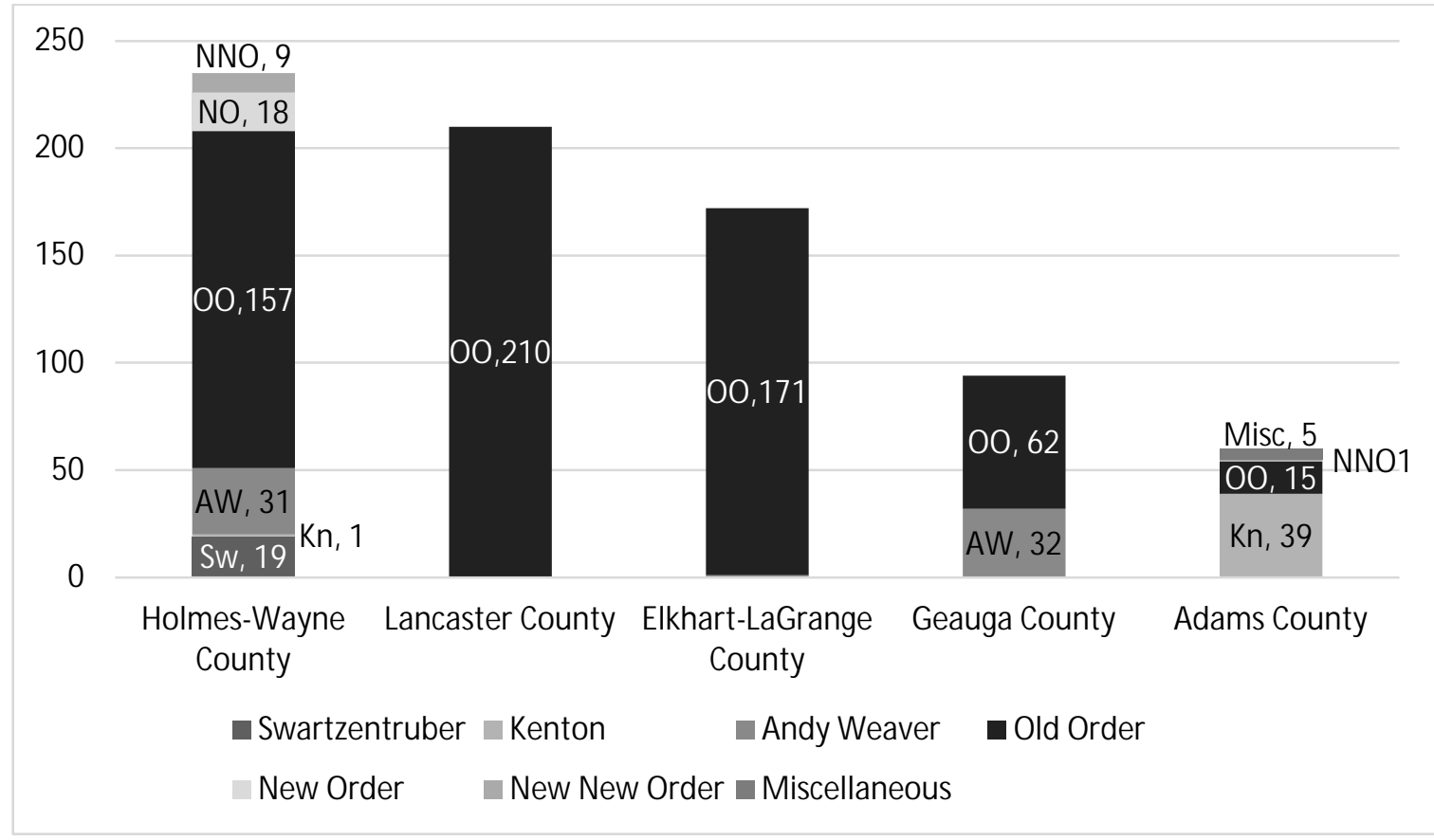

\section{Case 1: Holmes County, OH}

When Kraybill (1994) plotted social change in the Holmes County (OH) settlement, he plotted change across four affiliations-Swartzentruber, Andy Weaver, Old Order, and New Order. When Hurst and McConnell (2010) explained Holmes County Amish commonalities, they noted that these four affiliations account for approximately $97 \%$ of all church districts. This fouraffiliation scheme is useful for conceptual and statistical analysis. The "traditional-modified" scheme that I am proposing will retain these four affiliations but will include two New Order groups and the Kenton affiliation.

When Hurst and McConnell explain the diversity of the Holmes County Amish, they posit three Swartzentruber, two Old Order, and three New Order affiliations. With single-district Stutzman-Troyer and Roman affiliations included, Hurst and McConnell identify eleven distinct 
affiliations in the Holmes County settlement: Swartzentruber-Andy Weaver, SwartzentruberMose Miller, Swartzentruber-Joe Troyer, Stutzman-Troyer, Roman, Andy J. Weaver (Dan), Old Order, Old Order Tobe, New Order, New Order Tobe, and New Order Christian Fellowship.

If an affiliation is a group of church districts that associate with each other, and association exists when districts exchange ministers and the holy kiss, then it would seem that the Swartzentruber Amish across the continent should be separated into six or more distinct affiliations, and the three Holmes County-based affiliations of Hurst and McConnell would stand. But this move is not justified for three reasons. First, each Swartzentruber faction looks primarily to Sam Yoder for their identity, not the contemporary Swartzentruber leaders who were at the center of the Jeck Jecky or Andy Weaver Swartzentruber divisions. Second, the Swartzentruber divisions were largely the result of personality clashes or miscommunication rather than disagreements about doctrine or community practices. If personal animosity was not involved, these separate Swartzentruber factions would probably fellowship together. Third, doctrines and practices are nearly identical across Swartzentruber groups. Only the "Jeck Jecky" group objects to a doctrinal point held by the other Swartzentruber groups. Differences in lifestyle and dress are so minor that even Swartzentruber people find it difficult to know which group another Swartzentruber person comes from without asking. And finally, all Swartzentruber factions except the "Jeck Jecky" group excommunicate and shun a member who leaves their group-no matter what type of church they join. Because the Swartzentruber factions share a common identity, have similar community practices and doctrinal beliefs, have nearly identical convictions regarding technology, and have common disciplinary procedures, their refusal to formally fellowship together is insufficient reason to divide them into separate affiliations.

The Stutzman-Troyer Amish fellowship with church districts that practice strict shunning and are quite restrictive regarding technology_-for example, they will not fellowship with Ashland $(\mathrm{OH})$ or Stanwood (MI) because these settlements permit indoor flush toilets. The same philosophy undergirds the churches in Kenton $(\mathrm{OH})$ but Kenton will not fellowship with the Stutzman-Troyer Amish because of tobacco usage. As a result, Stutzman-Troyers are best classified as Andy Weaver Amish. Their origin from and disassociation with the Swartzentrubers makes the Stutzman-Troyer distinction more a figment of history than basis to establish them as separate from the larger Andy Weaver affiliation.

In the 1940s, a group broke away from the Stutzman-Troyer Amish. This group is known as the Tobe Church. In the 1960s, they divided into Old Order Tobe and New Order Tobe. The Old Order Tobe churches are best classified as Old Order-mainstream because they arose as a result of idiosyncratic causes and have reunited with the mainstream Old Orders. An irregularity in the ordination of the first Tobe bishop (before there were separate Old Order Tobe and New Order Tobe factions) causes some church leaders to shy away from this group and they tend to have limited cross-settlement ties, but most of the criticism comes from the Andy Weaver and Kenton circles, not the mainstream Old Orders that the Tobe churches formally fellowship with. 
Hurst and McConnell identify three distinct New Order affiliations: New Order, New Order Tobe, and New Order Christian Fellowship. Nationally, the New Order Amish have four distinct points of origin. In the 1950s, Amish churches that did not tolerate tobacco but permitted electricity from the public utility lines and tractors in the fields were dubbed "New Order." This today includes congregations in Guthrie (KY), Union Grove (NC), Spencer (WI), and elsewhere (but not Holmes County). I call this the "Traditional Electric” subgroup of New Orders.

The second New Order group emerged in the 1970s, a result of theological differences among mainstream Old Orders in Holmes County. Families that supported more evangelical emphases formed a separate circle of churches and were called "New Order" but did not permit electricity from public utility lines or tractors for field work. I call these the "Non-electric" New Order subgroup.

In the 1980s, a group broke away from the Non-electric New Orders-known locally as New Order Christian Fellowship. These districts permit tractors in the field, electricity from the public utility line, mobile phones (and in some cases smartphones with internet access), and computers. Their theology is somewhat distinct from the evangelical thought of the Non-electric group and they strongly emphasize missionary work. Because the New Order Christian Fellowship is much more lenient technologically and has distinct theological emphases and a distinct identity, they do not fellowship with the main body of New Orders in Holmes County or the Traditional Electric subgroup, but do fellowship with several other settlements including Oakland, MD.

The Holmes County "Non-electric” New Orders are in partial fellowship with the Traditional Electric group. Because of similarities in doctrine, shared community practices, and disciplinary understandings, these two groups should be kept together under the New Ordertraditional label.

The New Order Tobe and New Order Christian Fellowship should also be kept together because they have similar positions on technology (permitting tractors for field work and electricity from the public utility line) and are in full fellowship with each other. Although they have different origins-New Order Tobe came from the Tobe movement which broke away from the Stutzman-Troyer church in 1940, and New Order Christian Fellowship formed as a result of a division in the main body of Holmes County New Orders - similarities in technological usage and attaining full fellowship suggests that they have come together sufficiently to identify them as a single affiliation, which I will call "New New Order." Only identifying one New Order affiliation seems too little but identifying four separate groups a bit too much.

The single Roman district, a late 1950s division from the Old Orders, has been in full fellowship with the Amish in the Kenton $(\mathrm{OH})$ community. This fellowship also associates with a group that has fully left the Swartzentrubers, the Abe Miller churches (all outside Holmes County). The Abe Miller churches originated primarily from the Swartzentruber Amish in 
Ethridge (TN) because of objections to tobacco use and morally questionable courtship practices. The Abe Millers are also highly restrictive regarding technology. The Abe Miller churches wanted to continue the Swartzentruber practice of excommunicating a member for going to any other church group. However, church leaders in Kenton did not permit this to happen. As a result, the Abe Miller congregations operate under informal leadership from Kenton, along with several affiliated congregations located in other states. The Roman district would represent the single instance of this affiliation in Holmes County (which, as of this writing, appears to be in the process of disbanding).

The break-down of affiliations in Holmes County is presented in Figure 1. This sixaffiliation model works well in Holmes County. It works equally well outside Holmes County in untested areas, as I show with the next case.

\section{Case 2: Adams County, IN}

There are seven non-communing groups in Adams County. How would the traditionalrevised model apply to the Adams County situation?

The largest unit is the Joe L. group with 39 districts. They fellowship with the Amish in Kenton $(\mathrm{OH})$, share similar disciplinary procedures, and have similar technology restrictions, so they would be included in the Kenton affiliation. The next largest group is the Shetler group with 15 church districts. The Shetlers have similar disciplinary procedures as the districts in ElkhartLaGrange but a much more restrictive technological stance. There have been misunderstandings between the Shetlers and the Amish in Elkhart-LaGrange that led to a schism in Adams County, the breakaway faction (known as the "Amos E \& Mervin Hilty” group) claiming to fellowship in full with Elkhart-LaGrange. In spite of the schism, both groups claim to fellowship with ElkhartLaGrange and other mainstream Old Order congregations, so they are best understood as mainstream Old Orders.

Among the remaining groups in Adams County, there is a so-called "New Order" district, two or three Christner districts that shun every other Amish group (but declining numerically and likely to cease to exist in the not-so-distant future), a Wengerd group, and the Neuenschwanders (who broke away from the single Wengerd district). The New Order congregation affiliates with the New Order Christian Fellowship in Holmes County, so they would be classed as New New Order. The Christners would be considered miscellaneous (unaffiliated), as would the Wengerd and Neuenschwander groups, the former shunning all other Amish groups and the latter two holding unique practices. The Christners, Wengerds, and Neuenschwanders demonstrate well how small divisions arising from localized circumstances should not be treated as full-scale affiliations, for they are inconsequential at an inter-settlement level and are at risk of going extinct in due time.

To summarize, the Adams County settlement-perhaps the most complicated because splinter groups have rarely formed alliances with congregations in other communities-has one 
group (Joe L.) that affiliates with the Kenton Amish, two groups that are Old Order-mainstream (Shetlers / Amos E \& Mervin Hilty), one New New Order district, and three small unaffiliated units (Christners, Wengerds, Neuenschwanders) (see Figure 1).

\section{Case 3: Collapsing Table 8.1}

In this section, I show how the many affiliations from Table 8.1 can be reduced to six affiliations. If we apply the traditional-revised model to Table 8.1's “affiliations”...

- Swartzentruber: remains unchanged.

- Kenton: the Kenton and Abe Miller groups would be grouped together.

- Andy Weaver: the Buchanan/Medford, Geauga II, New Wilmington, Ashland, Fredericktown, and Byler affiliations end up under the same umbrella.

- Old Order-mainstream: 21 of the listings would be classed together, namely, Lancaster, Elkhart-LaGrange, Holmes Old Order, Geauga I, Swiss (Allen), Dover, Nappanee, Arthur, Daviess, Jamesport/Bloomfield, Michigan-related, Renno, Kalona, Kansas/Oklahoma, Milverton, Missouri/Illinois, Somerset, Tobe Hostetler, Milroy/West Union, Guys Mills/Fredonia, Aylmer, and Kokomo.

- New Order-traditional: New Order (Non-electric) and New Order (Traditional Electric) would be classed together.

- New New Order: the New Order-Tobe and New Order Fellowship would be joined.

The traditional-revised model not only draws many of Kraybill, Johnson-Weiner, and Nolt's 40 affiliations together, it also subdivides and re-situates church districts from the Swiss and Nebraska "affiliations" that should not be held together—because they disagree about disciplinary practices, have different positions on technology, and do not fellowship together. Districts from the Swiss (Adams) and Nebraska "affiliations" would be subdivided according to lines of fellowship, disciplinary standards, and technology use. Following case two above, the majority of Swiss (Adams) — the Joe L. group—would be classed as Kenton while the minority—Shetler group—would be classed as Old Order-mainstream. Anymore, nearly all Nebraska districts would be Andy Weaver, except for a few technologically progressive districts that fellowship with districts from the Old Order-mainstream affiliation.

Kraybill, Johnson-Weiner, and Nolt identify a "Reformist Amish” affiliation (labeled "Michigan-related" in Table 8.1) that seeks to remain in the Amish mainstream but promotes high moral standards for courtship and strictly prohibits tobacco usage. Are the Michigan-related Amish a distinct affiliation? According to the traditional model, probably not because they fellowship with mainstream Old Orders, and share very similar lifestyles and disciplinary standards with these communities. Their unwillingness to permit an Amish minister to preach if he uses tobacco is exceptional among the Amish. However, the Michigan-related congregations are better understood as an internal movement aimed at reforming moral and spiritual practices rather than a distinct affiliation. The traditional-modified model attaches importance to 
theological emphases and community practices, and the "Reformist Amish" certainly have uncommon theological emphases and community practices. However, in weighing all the variables, these emphases are not sufficiently unique to override the fact that they remain in full fellowship with Old Order districts throughout North America.

\section{Coping with Flukes}

Amish society is best understood as being composed of six affiliations and various unaffiliated congregations functioning alongside the six affiliations because their history does not align well with the history of any larger group and their practices represent such a minority position that they have been unable to form cross-settlement bonds that would take them from unaffiliated to a distinct affiliation. But the existence of unaffiliated congregations, as well as Lancaster's ambiguous relationship with the Andy Weaver affiliation, seems to challenge my case for only six Amish affiliations.

The presence of miscellaneous congregations seems to challenge the unity that the sixaffiliation model implies. Yet, in nearly every case, these miscellaneous congregations are unaffiliated because of a personality conflict or miscommunication between church leaders. Furthermore, these personality conflicts or miscommunications are usually local affairs, limited to their immediate context. And, as Hurst and McConnell (2010) described the situation in Holmes County, some groups are the result of "idiosyncratic conflicts that did not revolve around central doctrinal issues” (p. 40). In addition to the aforementioned Adams County cases, other miscellaneous examples include the Highway C Amish in Seymour, MO, and the "Christian Community” in Caneyville (KY) and its predecessor, Cookeville, TN. The most striking instance is the Bergholz $(\mathrm{OH})$ community, identified by Hurst and McConnell (2010) in Appendix B as "Sam Mullet" affiliation, in other words, an unaffiliated congregation. Their disassociation from other Amish congregations, together with the highly unorthodox practices of Bishop Sam Mullet, culminated in the highly-publicized beard cutting events. Since most of these unaffiliated districts are the result of interpersonal conflict, are local in scope, have idiosyncratic causes that keep these congregations from forming cross-settlement ties, and are rarely long-lived, these church districts are best considered unaffiliated congregations rather than distinct affiliations.

The Lancaster Amish technically fellowship with the Andy Weaver group because they practice strict shunning, but, in reality, they fellowship with Old Order, mainstream districts. The unwritten decision seems to be that Andy Weaver Amish ministers will try not to attend church in Lancaster County, or at least visit only the most conservative districts. The Andy Weavers have not officially disfellowshipped the Lancaster County Amish because of the role Lancaster plays in the broader Amish narrative, as not only the earliest settlement but also the source from which the majority of later Amish settlements derive. Their special status in the American narrative, settlement size, and firmness in holding to the strict shunning position have also dissuaded the Andy Weavers from taking an official, pubic stance on the technological progressivism of the Lancaster Amish. Furthermore, Lancaster County ministers gather annually for local ministers' 
meetings and, as a result, rarely attend ministers' meetings held by the Andy Weaver Amish. Also, because cultural differences make it difficult for individuals to make the jump from one group to the other, the Lancaster Amish are not considered a threat to more conservative Andy Weaver lifestyles. For these reasons, the Andy Weaver Amish seem content being formally linked to the Lancaster Amish but allowing them to actually fellowship with mainstream Old Order Amish congregations. As a result, Lancaster County Amish should be classed as Old Order, mainstream (Figure 1).

\section{Conclusion}

Affiliation has been a difficult term to define. Scholars have traditionally considered it a group of church districts that fellowship together and share a similar Ordnung. A more precise definition identifies disciplinary procedures and technological restrictiveness as constituent elements of Ordnung relevant for tracing lines of fellowship, and theology and community practices and shared identity as formative variables that have contributed to the growth of distinct affiliations. When this traditional-revised model is applied to the Amish, six distinct affiliations emerge-Swartzentruber, Kenton, Andy Weaver, Old Order-mainstream, New Ordertraditional, and New New Order-plus numerous unaffiliated church districts. This classification scheme reveals the diversity of the Amish without neglecting cross-settlement ties, common community practices and theology, and shared history that draw the Amish together.

Future studies could refine these categories and relate them to other fields of study, such as migration history and identity formation, and especially historical and systematic theology. For example, "community practices" is a term popularized by "Baptist” theologian William McClendon. It has a distinct theological meaning that is not implied in social-scientific analysis of the Amish. But these practices, especially the frequency that differences lead to church divisions, say something about their doctrine of the church. And understanding their doctrine of the church could help sociologists understand why certain affiliations create more social distance than others.

\section{Endnotes}

${ }^{1}$ Contact information: Christopher Petrovich (Кристофер ЏорЏ Петровић), Srpskih Junaka 15A (Српских Јунака 15A), Niška Banja, Srbija 18205 (Нишка Бања, Србија 18205)

${ }^{2}$ The "King churches" followed much the same path, except that members gradually defected into Amish-Mennonite circles until all churches were extinct. Prior to this gradual attrition, they filled a New Order Amish-type affiliation before the rise of the New Order-traditional affiliation. 


\section{References}

“Amish Population Profile 2016.” Young Center for Anabaptist and Pietist Studies, Elizabethtown College. http://groups.etown.edu/amishstudies/statistics/amish-populationprofile-2016.

Anderson, Cory, and Joseph Donnermeyer. 2013. “Where Are the Plain Anabaptists?” Journal of Amish and Plain Anabaptist Studies 1(1):1-25.

Hostetler, John. 1968. Amish Society [revised edition]. Baltimore, MD: Johns Hopkins University Press.

Hurst, Charles, and David McConnell. 2010. An Amish Paradox: Diversity and Change in the World's Largest Amish Community. Baltimore, MD: Johns Hopkins University Press.

Johnson-Weiner, Karen. 2010. New York Amish: Life in the Plain Communities of the Empire State. Ithaca, NY: Cornell University Press.

Johnson-Weiner, Karen. 2014. "Technological Diversity and Cultural Change among Contemporary Amish Groups." Mennonite Quarterly Review 88(1):5-22.

Kraybill, Donald. 2001. The Riddle of Amish Culture. Baltimore, MD: Johns Hopkins University Press.

Kraybill, Donald, and Marc Olshan. 1994. The Amish Struggle with Modernity. Hanover, NH: University Press of New England.

Kraybill, Donald, Karen Johnson-Weiner, and Steven Nolt. 2013. The Amish. Baltimore, MD: Johns Hopkins University Press.

Meyers, Thomas, and Steven Nolt. 2005. An Amish Patchwork. Bloomington, IN: Indiana University Press.

Nolt, Steven, and Thomas Meyers. 2007. Plain Diversity: Amish Cultures \& Identities. Baltimore, MD: Johns Hopkins University Press.

Petrovich, Christopher. 2014. "Technology in the Service of Community: Identity and Change among the Andy Weaver Amish.” Mennonite Quarterly Review 88(1):23-44.

Scott, Stephen. 2011. “Amish Groups, Affiliations, and Categories.” Unpublished. 